\title{
Investigation of produced waters radioactivity of oil and gas deposits in the Dnieper-Donets province
}

Plyatsuk L. D., Burla O. A., Ablieieva I. Yu. , Hurets L. L., Roy I. O.

Sumy State University, 2 Rymskogo-Korsakova St., 40007, Sumy, Ukraine

\author{
Article info: \\ Paper received: \\ The final version of the paper received: \\ Paper accepted online:
}

October 10, 2017

November 29, 2017

December 6, 2017
*Corresponding Author's Address:

i.ableyeva@ecolog.sumdu.edu.ua

\begin{abstract}
The process of radioactive pollution of produced waters, oilfield equipment, oil-contaminated soils and sludge is widely spread and differs within the various oil and gas regions. Formation waters contained radioactive element isotopes become the significant source and cause of elevated level of equivalent dose power and as a consequence, an increase in the incidence among the population. The author's idea is formulation of specific recommendations on the decontamination of the investigated objects by conducting the necessary appropriate experimental studies. The purpose of the article is to determine the content of radionuclides, $\gamma$ - and $\alpha$-emitters in technogenic objects of Bugruvate oil and gas fields, and to reveal the relationship with the features of mineralogical composition, geological structure and technological process. The $\gamma$-spectrometric analysis was used to determine the radionuclide composition of the natural radiators of the ${ }^{238} \mathrm{U}\left({ }^{226} \mathrm{Ra},{ }^{214} \mathrm{Po},{ }^{214} \mathrm{Bi}\right)$ and ${ }^{232} \mathrm{Th}\left({ }^{228} \mathrm{Ac},{ }^{212} \mathrm{~Pb},{ }^{212} \mathrm{Bi}\right)$ series in samples of technological sludge, oil, individual soil samples and water. The content of radionuclides of $\alpha$-emitters was determined using separate radiochemical techniques. It was investigated that the radioactivity of the formation water is mainly determined by ${ }^{226} \mathrm{Ra}$ and ${ }^{228} \mathrm{Ra}$ and the products of their decay.
\end{abstract}

Keywords: radioactive pollution, $\gamma$ - spectrometric analysis, radiochemical analysis, radioactive oilfield equipment, equivalent dose power, sludge decontamination.

\section{Introduction}

Natural waters that have mobile contact in all systems of the earth's crust (with rocks, ores, minerals, soils and living organisms) become carriers of radioactive element isotopes [1-3]. The formation waters of oil deposits contain isotopes of radium: ${ }^{223} \mathrm{Ra},{ }^{224} \mathrm{Ra},{ }^{228} \mathrm{Ra}$ and ${ }^{226} \mathrm{Ra}$, the concentration of the last isotope reaches $10^{3}-10^{5} \mathrm{~Bq} / \mathrm{m}^{3}$, which does not comply with environmental safety standards. Based on the analysis of the content of radium in formation waters, it is determined that the hard waters are enriched with isotopes of this elements, in contrast to soft oil waters that contain no more than $10^{-12} \% \mathrm{Ra}$. In this connection, the question arose of a deeper study of the causes and sources of enrichment of hard waters with radium and its isotopes $-{ }^{224} \mathrm{Ra}$ and ${ }^{228} \mathrm{Ra}$.

Under natural conditions, the appearance of waters with high radium content is facilitated by the collision of groundwater with uranium ores, or the high mineralization of waters and the presence of alkaline earth metal chlorides (chloride-sodium-calcium water) in them with low bicarbonate and sulphate content. It has been established [4] that the concentration of radium increases in parallel with the increase in the content $\mathrm{Na}^{+}, \mathrm{K}^{+}, \mathrm{Ca}^{2+}$, $\mathrm{Mg}^{2+}, \mathrm{Cl}^{-}$. The dependence of the content of radium and thorium on the sulfate and carbonate content of waters has a similar nature. With a decrease in the concentrations of $\mathrm{SO}_{4}{ }^{2-}$ and $\mathrm{CO}_{3}{ }^{2-}$, the concentrations of ${ }^{226} \mathrm{Ra}^{2}$ and ${ }^{224} \mathrm{Ra}$ in groundwater increase. It is determined that the ratio between the content of ${ }^{226} \mathrm{Ra}$ and the total mineralization for different stratigraphic complexes varies in the range from 0.01 to 4.6 .

According to authors [5] equipment in oil fields can contain radioactive accumulations and radioactive sludge that form crusts or deposits. These accumulations are formed as a result of the interaction of equipment with formation water due to changes in temperature, pressure and mineralization, when the water is released to the surface, as well as during the separation of oil from associated water. They are a mixture of carbonate and sulfate 
minerals, among which barite is found, which easily includes radium into its structure.

Studies of the radioactivity of oilfield equipment and contaminated soils in oil fields [6-8] show that the radium waters of oil and gas bearing provinces contain from $1 \cdot 10^{-9}$ to $1.2 \cdot 10^{-8} \mathrm{~g} / \mathrm{l}$ of radium. Such water, after separating the condensate and methanol, is pumped into the aquifer at a depth of about $3000 \mathrm{~m}$. Fallout with specific activity from 1 to $100 \mathrm{kBq} / \mathrm{kg}(50-5000 \mu \mathrm{R} /$ year) is collected and transported to a storage warehouse for slurries, where they are stored in containers.

Pump-compressor pipes (PCP) raised from the depths of $2-4 \mathrm{~km}$ have an activity of 100 to $6000 \mu \mathrm{R} / \mathrm{h}$, owing to which they can be attributed to radioactive waste in accordance with modern classification [9]. Apart from the additional costs of cutting and transporting pipes, complex environmental problems arise dealing with the releasing of natural radionuclides into the region environment. At the same time, in terms of its mineralogical composition, radioactive deposits of pipes are rather heterogeneous, depending on the depth of extraction and deposits. Some of the lightly soiled pipes can be deactivated by simple methods and used in the local economy or as scrap metal.

The safety of maintenance personnel and the protection of the environment from the uncontrolled spread of radionuclides are the main factors during decontamination. Therefore, decontamination can be carried out using methods that combine a high degree of mechanization of all technological operations, remote control of processes and reliable localization of radionuclides to a limited extent $[10,11]$.

Different methods of decontaminating equipment and structures using various means, technical devices and special substances are used depending on the characteristics that occur during removing radioactive substances. In connection with this, it is necessary to conduct a study of the radioactive characteristics of formation waters as the main source of contamination of equipment, pipes, and environmental objects.

Thus, the aim of this paper is to determine the content of radionuclides, $\gamma$ - and $\alpha$-emitters in technogenic objects of Bugruvate oil and gas fields, and to reveal the relationship with the features of mineralogical composition, geological structure and technological process.

\section{Methods}

\subsection{Materials}

The measurements of the exposure dose rate and radon concentration in the air at the sites of the Kachanovka pumping station of oil, the Bugruvate deposit, at the temporary radioactive waste storage site were performed during field work. Sampling of technological media and objects was carried out simultaneously with the measurements. Also, the territory of Bugruvate village was tracked, which is located in the zone of influence of the Bugruvate deposit, sampling of natural objects was done.

To assess the radioactive effect on personnel, the content of radionuclides in the formation water, oil, various sediments and silt taken from the process equipment (pipelines, tanks, settling tanks) was measured. Pollution of the environment was assessed by the content of radionuclides in surface and groundwater, and soil [12]. Samples were taken at different sections of the technological process for the analysis: mineral deposits from the inner surface of the tank (1b), mineral deposits from the inner surface of the separation vessel outlet $(2 b)$, bitumen deposits of PCP (3b), mineral-bitumen deposits from the other outlet of the separation tank (4b), salt deposits from the external surface of pumping equipment (5b), mineral deposits from the inner surface of the pipe (6b), degassed water-oil mixture (1n), technological sludge from the bottom of the broken sand trap $(1 \mathrm{~m})$, sludge from the bottom of the operating sand trap $(2 \mathrm{~m})$ (see table 1$)$.

Table 1 - Basic physical characteristics of samples

\begin{tabular}{|l|l|}
\hline $\begin{array}{l}\text { Sample } \\
\text { number }\end{array}$ & \multicolumn{1}{|c|}{ Physical properties of sediments } \\
\hline $1 \mathrm{~b}$ & $\begin{array}{l}\text { Deposits of tuberous lamellar dark brown in } \\
\text { colour 2-3 mm thick. The colour of the } \\
\text { broken plates is black. Rough, easily } \\
\text { crushed into powder in a mortar. }\end{array}$ \\
\hline $2 \mathrm{~b}$ & $\begin{array}{l}\text { Plate grey in colour, very dense, brittle, } \\
\text { easily crushed into powder. }\end{array}$ \\
\hline $3 \mathrm{~b}$ & $\begin{array}{l}\text { Fatty paste-like mass of black colour with } \\
\text { the smell of oil. }\end{array}$ \\
\hline $4 \mathrm{~b}$ & $\begin{array}{l}\text { Mineral-bituminous crustaceans are dark } \\
\text { brown in colour. Mechanically brittle, easily } \\
\text { kneaded. Strongly smeared. }\end{array}$ \\
\hline $5 \mathrm{~b}$ & $\begin{array}{l}\text { Crystals of salt. } \\
\text { For all characteristics there corresponds a } \\
\text { sample 2b. }\end{array}$ \\
\hline $1 \mathrm{~b}$ & Viscous black liquid. \\
\hline $1 \mathrm{~m}$ & $\begin{array}{l}\text { Suspension of oil and mineral sludge of } \\
\text { black colour. }\end{array}$ \\
\hline $2 \mathrm{~m}$ & $\begin{array}{l}\text { Suspension of oil and mineral sludge of } \\
\text { black colour. }\end{array}$ \\
\hline
\end{tabular}

For laboratory measurement, 4 soil samples were taken: $1 \mathrm{~s}-4 \mathrm{~s}$. Samples of soil were selected on virgin lands. Depth of selection was 5-6 cm. In appearance, the soil can be attributed to chernozem.

Samples of formation water were collected at the following points in the process:

- an oil trap near the village of Kachanivka (sample 1f);

- input collector Bugruvate sewage pumping station (SPS) (sample 2f);

- outlet collector Bugruvate SPS (sample 3f).

Immediately after the selection, the water samples were clear and no turbidity was observed. After three days in the water samples, a small amount of precipitate of iron hydroxide precipitated, which was filtered out on a paper filter "blue tape". A few days later a similar precipitate again occurred in the samples, which is due to oxidation of bivalent iron to trivalent iron. 
In this paper, the specific radioactivity of water in the river Khukhra and in some sources of drinking water wells were measured. Because of the low content of radionuclides, their determination in these waters was carried out by radiochemical methods after preliminary concentration by evaporation.

\section{$2.2 \gamma$-spectrometric analysis}

A $\gamma$-spectrometric unit EVT consisting of a DGDK$100 \mathrm{~V}-3$ semiconductor detector, a single-board spectrum analyzer No. 21 and a SELERON 1,2 computer was used for measurements. The relative error in the measurement was not more than $20 \%$. Exposure time was determined by the radioactivity of the samples $-3600 \mathrm{~s}$. The measurements were carried out in the standard Dent geometry [13].

The aim of the $\gamma$-spectrometric analysis is to determine the radionuclide composition of the natural radiators of the ${ }^{238} \mathrm{U}\left({ }^{226} \mathrm{Ra},{ }^{214} \mathrm{Po},{ }^{214} \mathrm{Bi}\right)$ and ${ }^{232} \mathrm{Th}\left({ }^{228} \mathrm{Ac},{ }^{212} \mathrm{~Pb}\right.$, ${ }^{212} \mathrm{Bi}$ ) series in samples of technological sludge, oil, individual soil samples and water.

To determine the radionuclides ${ }^{224} \mathrm{Ra},{ }^{226} \mathrm{Ra}$ and ${ }^{222} \mathrm{Rn}$, a QUANTULUS liquid scintillation spectrometer was used [14].

\subsection{Radiochemical analysis}

The content of radionuclides of $\alpha$-emitters was determined using separate radiochemical techniques [15]. Preliminary preparation of sediment, silt and soil samples before radiochemical analysis consisted of the following:

1. Taking samples weighing $1-2 \mathrm{~g}$.

2. Calcination of samples at $500^{\circ} \mathrm{C}$ for 3 hours.

3. Decomposition of samples in mineral acids.

The sample $2 \mathrm{~b}$ was very poorly soluble in such acids as hydrochloric, sulphuric, nitric and hydrofluoric. More complete dissolution was observed after fusion of the sample with potassium hydroxide, but a small residue after dissolving the alloy in hydrochloric acid and evaporation in soda remained. The sample contained little iron. Its chemical composition was mainly determined by sulphates and silicates of alkaline earth metals.

Samples $1 b, 3 b$, and $4 b$ were mostly completely dissolved in the $6 \mathrm{M}$ solution of hydrochloric acid, but with sediment in solutions of samples $3 \mathrm{~b}$ and $4 \mathrm{~b}$, precipitation of silicic acid after cooling was observed. The basis of the chemical composition is represented by various iron oxides.

The principle of radiochemical concentration and uranium extraction is based on its sorption on the Dowex-1 anion in a hydrochloric acid medium, and thorium in a nitrate medium [16]. Samples to measure the activity of uranium and thorium were prepared by an electrochemical method. To determine the chemical composition of uranium, a radioactive label ${ }^{232} \mathrm{U}$ was used. The chemical composition of thorium was estimated from preliminary analyses of identical samples with the introduced reference activity and was equal to $70 \%$. The $\alpha$-activity was measured on an ORTEC $\alpha$-spectrometer. The sensitivity of the techniques for these radionuclides is $0.001 \mathrm{~Bq}$ per sample.

\section{Results}

The results of $\gamma$-spectrometric analysis of radionuclide activity in the investigated process sediments, sludge and oil are given in Table 2 .

Table 2 - Results of $\gamma$-spectrometric measurements of radionuclide activity in process sediments, sludge and oil

\begin{tabular}{|c|c|c|c|c|c|c|}
\hline \multirow{2}{*}{ 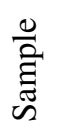 } & \multicolumn{6}{|c|}{ Specific activity of radionuclides, $\mathrm{kBq} / \mathrm{kg}$} \\
\hline & ${ }^{226} \mathbf{R a}$ & ${ }^{214} \mathrm{Bi}$ & ${ }^{214}$ Po & ${ }^{228} \mathrm{Ac}$ & ${ }^{212} \mathrm{Bi}$ & ${ }^{212} \mathbf{P b}$ \\
\hline $1 b$ & 16.2 & 16.2 & 16.2 & 9.83 & 16.9 & 1.73 \\
\hline $2 b$ & 1270 & 1270 & 1270 & 3.95 & 1350 & 1.85 \\
\hline $3 b$ & 0.85 & 0.85 & 0.85 & 0.38 & 0.85 & 0.5 \\
\hline $4 \mathrm{~b}$ & 47.5 & 47.5 & 0.87 & 4.93 & 50.2 & - \\
\hline $5 b$ & 0.105 & 0.106 & 47.5 & 0.108 & 0.102 & 0.07 \\
\hline $6 \mathrm{~b}$ & - & - & 0.107 & - & - & - \\
\hline $1 \mathrm{n}$ & 0.012 & - & - & 0.003 & 0.012 & - \\
\hline $1 \mathrm{~m}$ & 3.87 & 3.8 & 3.8 & 1.547 & 3.88 & 1.07 \\
\hline $2 \mathrm{~m}$ & 0.36 & 0.36 & 0.373 & 0.175 & 0.34 & 0.113 \\
\hline
\end{tabular}

The results for $\alpha$-emitted radionuclides in the investigated sediments and sludge are given in Table 3.

Table 3 - Content of $\alpha$-emitted radionuclides in sediments and sludge determined by radiochemical methods

\begin{tabular}{|c|c|c|c|c|}
\hline \multirow{2}{*}{ Sample } & \multicolumn{4}{|c|}{ Specific activity of radionuclides, Bq/kg } \\
\cline { 2 - 5 } & ${ }^{\mathbf{2 3 4}} \mathbf{U}$ & ${ }^{\mathbf{2 3 8}} \mathbf{U}$ & ${ }^{\mathbf{2 2 8}} \mathbf{T h}$ & ${ }^{{ }^{\mathbf{2 3 2}} \mathbf{T h}}$ \\
\hline 1b & $3.51 \pm 0.8$ & $2.85 \pm 1.1$ & $290.1 \pm 18$ & $<1.0$ \\
\hline 2b & $7.58 \pm 1.1$ & $2.97 \pm 1.1$ & $643.2 \pm 65$ & $<1.0$ \\
\hline 3b & $0.98 \pm 0.6$ & $0.77 \pm 0.3$ & $364 \pm 36$ & $<1.0$ \\
\hline 4b & $2.97 \pm 1.1$ & $2.50 \pm 1.1$ & $1570 \pm 160$ & $<1.0$ \\
\hline 1m & $8.50 \pm 1.2$ & $8.90 \pm 1.2$ & $63 \pm 6.5$ & $<1.0$ \\
\hline
\end{tabular}

Determination of activity of radionuclides in soil samples was carried out according to the methods of analysis of deposits in technological processes. Figure 1 shows the results of $\gamma$-spectrometric measurements and radiochemical analysis.

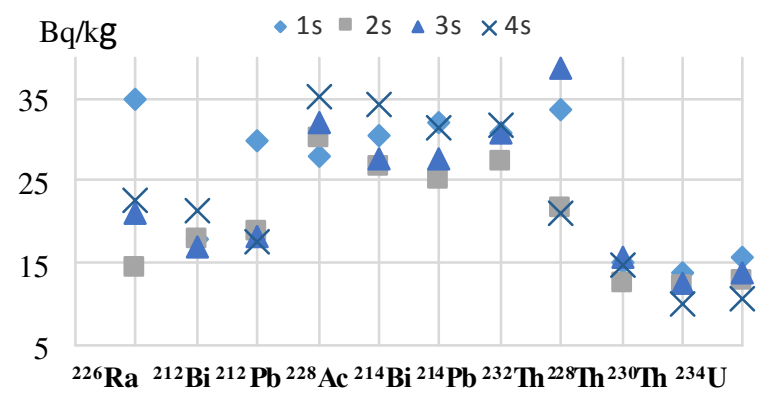

Figure 1 - Radionuclide content in soil samples 
The results of analyzes (fig. 1) show that the abnormally high content of any radionuclide caused by technogenic factors is not observed in soil samples. The content of radionuclides in the selected samples of the soil does not differ from the average values characterized for the given area. There is a discrepancy between the ${ }^{228} \mathrm{Th}$ content calculated from $\gamma$-spectrometric measurements of ${ }^{228} \mathrm{Ac}$ and the results of radiochemical analyzes. The results of analyzes of $\gamma$-spectrometric measurements are approximately one and a half to two times higher than the results of radiochemical analyzes using $\alpha$-spectrometric measurements.

Formation water is a highly saline solution that separates from oil after it is lifted to the surface. The salt composition of the reservoir water contains mainly sodium chlorides with a concentration of $100-160 \mathrm{~g} / \mathrm{dm}^{3}$. As a result of the impact on the mineral deposits of the deposit, water leaches not only the elements of minerals (iron, aluminum, manganese, etc.), but radionuclides, including daughter radionuclides of the thorium and uranium series. Further, during the processing of the oilwater mixture, precipitation and concentration of stable elements and radionuclides occur on the process equipment. Thus, the formation water is the main supplier of radioactive elements to the surface; therefore it is necessary to introduce a control over the content of radionuclides in them.

The results of radionuclides content in water are given in Table 4.

Table 4 - Content of radionuclides in produced waters

\begin{tabular}{|c|c|c|c|c|}
\hline \multirow{2}{*}{ Sample } & \multicolumn{4}{|c|}{ Specific activity of radionuclides, Bq/ $\mathrm{dm}^{3}$} \\
\cline { 2 - 5 } & ${ }^{\mathbf{2 2 4}} \mathbf{R a}$ & ${ }^{\mathbf{2 2 6}} \mathbf{R a}$ & ${ }^{\mathbf{2 2 2}} \mathbf{R n}$ & ${ }^{\mathbf{2 2 8}} \mathbf{R a}$ \\
\hline 1f & $1.57 \pm 0.31$ & $27.4 \pm 4.8$ & 16.87 & $3.20 \pm 0.47$ \\
\hline 2f & $3.98 \pm 1.1$ & $28.8 \pm 5.9$ & 19.45 & $5.38 \pm 0.8$ \\
\hline 3f & $5.51 \pm 1.1$ & $39.8 \pm 7.8$ & 19.77 & $5.57 \pm 0.83$ \\
\hline & ${ }^{\mathbf{2 3 0}} \mathbf{T h}$ & ${ }^{\mathbf{2 3 2}} \mathbf{T h}$ & ${ }^{\mathbf{2 3 4}} \mathbf{U}$ & ${ }^{\mathbf{2 3 8}} \mathbf{U}$ \\
\hline 1f & $0.058 \pm 0.02$ & $<0.001$ & $0.010 \pm 0.002$ & $0.007 \pm 0.002$ \\
\hline 2f & $0.19 \pm 0.02$ & $<0.001$ & $0.013 \pm 0.003$ & $0.006 \pm 0.003$ \\
\hline 3f & $0.068 \pm 0.02$ & $<0.001$ & $0.012 \pm 0.03$ & $0.005 \pm 0.003$ \\
\hline
\end{tabular}

From the results of Table 4 it can be seen that the radioactivity of the formation water is mainly determined by ${ }^{226} \mathrm{Ra}$ and ${ }^{228} \mathrm{Ra}$ and the products of their decay. This is due to the high leaching power of alkaline earth elements with non-sulfate chloride brines. Produced water contains a very small amount of maternal radionuclides of thorium and uranium, in particular $0.005-0.007 \mathrm{~Bq} / \mathrm{dm}^{3}$ of ${ }^{238} \mathrm{U}$ and $0.01-0.015$ of ${ }^{234} \mathrm{U}$. From a geological point of view, it can be concluded that the presence of these elements in rocks contained in oil fields has a subordinate nature without the formation of intrinsic minerals in these rocks.

\section{Discussion}

The waters of the oil and gas bearing region of the Dnieper-Donets province are compositionally classified as chloride-sodium-calcium, which is a prerequisite for an increased level of radioactivity. This is because the high mineralization of water and the content of chlorides of alkaline earth metals in it, on the one hand, reduces the adsorption of radium, and on the other hand it facilitates the processes of cation exchange and, thereby, the increase in the level of leaching of radium from rocks.

A study of the radiation situation within the DnieperDonets cavity showed the problem of contamination of industrial equipment with natural radionuclides (NRN) in all oil-producing enterprises: Chernigivnaftogaz, Poltavanaftogaz, Okhtyrkanaftogaz and the territories of oil and gas refineries. Maximum levels of the equivalent dose power (EDP) from industrial equipment up to 60 $\mu \mathrm{Sv} / \mathrm{h}\left(6.0 \cdot 10^{3} \mu \mathrm{R} / \mathrm{h}\right)$ belong to the production of Okhtyrkanaftogaz. The equivalent dose power for the first two enterprises was at the level of $10 \mu \mathrm{Sv} / \mathrm{h}\left(1.0 \cdot 10^{2} \mu \mathrm{R} / \mathrm{h}\right)$.

However, from the variety of contaminated equipment, it is possible to single out a part of PCP with high EDP values up to $6000 \mu \mathrm{R} / \mathrm{h}$. The activity of these pipes is associated with the radio-borate, which is part of the complex hydrothermal complex. Lead glance $(\mathrm{PbS})$ and native nickel are laid directly on the metal pipes. At the same time, the mineral mass of galena and nickel is armored by a layer $(2-4 \mathrm{~mm})$ of radiobarite. The presented hydrothermal complex of minerals is firmly connected with the metal of pipes and is practically not subject to changes in the investigated complex of chemical and physical influences. Industrial equipment of this group is recommended for disposal taking into account the high radioactivity and chemical stability of mineral neoplasms.

The maximum total activity of ${ }^{226} \mathrm{Ra}$ on the equipment walls does not exceed $100 \mathrm{GBq}$. The rate of emanation of mineral formations can be taken as $2.3 \cdot 10^{-6} \% / \mathrm{s}$ or $2300 \mathrm{~Bq} / \mathrm{s}$. The maximum content of ${ }^{226} \mathrm{Ra}$ in radioactive sludge is $4000 \mathrm{~Bq} / \mathrm{kg}$. The maximum activity of ${ }^{226} \mathrm{Ra}$ on sites is about $1.63 \cdot 10^{9} \mathrm{~Bq}$ under the condition of one year's accumulation time. The approximate rate of radon emanation from slurries is $8.2 \cdot 10^{-6} \% / \mathrm{s}$. The radon exhalation from the desiccation site is $130 \mathrm{~Bq} / \mathrm{s}$ or $4 \mathrm{GBq} / \mathrm{year}$. The outflow will be formed almost at ground level. The total release of radon as a result of production activities with the site of the Bugruvate deposit will not exceed $730 \mathrm{~Bq} / \mathrm{s}$.

Decontamination of slurries aimed at reducing the formation of radioactive sludge in reservoirs of formation water, is recommended to carry out by changing the $\mathrm{pH}$ of the produced water. For this, 11 of $\mathrm{HCl}$ per $1 \mathrm{~m}^{3}$ of produced water is added, which provides a $\mathrm{pH}$ value at a level of 2 units. The slurry solution is settled for 1 month. The permissible level of radioactivity of the slurry is $9 \mathrm{kBq} / \mathrm{kg}$, after which the slurry is mixed with finely dispersed sand in a mixer with a proportion of 1:5 and is subsequently used in road construction. 


\section{Conclusions}

The radiation effect of the Bugruvate oil-producing complex on the environment is mainly due to the removal of ${ }^{238} \mathrm{U}$ decay products from the industrial territory. Isotopes ${ }^{226} \mathrm{Ra},{ }^{222} \mathrm{Rn},{ }^{210} \mathrm{~Pb}$, and ${ }^{210} \mathrm{Po}$ are the main doseforming radionuclides when exposed to the population. The total amount of radon released into the environment will be determined by two aggregated sources of emissions. The first is the isolation, impregnation through the breathing valves of the systems, flares of residual gas combustion, leakiness of the armature, flanges in the entire process cycle of oil separation and treatment of formation water. This emission source has a relatively stable release rate of about $200 \mathrm{~Bq} / \mathrm{s}$ at a uniform production capacity of the field.

As the equipment becomes contaminated, this component of the radon emission can increase to $600 \mathrm{~Bq} / \mathrm{s}$. The second is radioactive gas emissions in the area of drying the sediment from the sludge. Here, the volumes of emissions and, at the same time, the outflows will increase as the radioactive sediment accumulates up to $130 \mathrm{~Bq} / \mathrm{s}$ and decrease stepwise as the next consignment is transported to the disposal site.

With conservative estimates of the equivalent dose of external $\gamma$-radiation, the total specific activity of ${ }^{226} \mathrm{Ra}$ and ${ }^{228} \mathrm{Ra}$ should be multiplied by a factor of $0.02\left[\mathrm{bp} /\left(\mathrm{cm}^{2} \cdot \mathrm{min}\right)\right] /[\mathrm{Bq} / \mathrm{kg}]$ to determine the electrons fluxes from the objects of Okhtyrka oil and gas production department (OGPD) that are contaminated by the decay products of the radium radionuclide isotopes.

Usage of the emanation factor for radon isotopes of $1 \%$ for dense sediments and $4 \%$ for wet dispersions of mineral precipitation can be recommended to determine the concentration of radon decay products in closed reservoir facilities in the oil fields of the Okhtyrka OGPD during dose estimates. The emanation rate is $2.3 \cdot 10^{-6} \% / \mathrm{s}$ and $8.2 \cdot 10^{-6} \% / \mathrm{s}$ for sediments and slimes, respectively (the percentages are taken from the total activity of the parent radium in the substance that emits emanation).

\section{References}

1. Botezatu, E., \& Grecea, C. (2004). Radiological impact assessment on behalf of oil/gas industry. The journal of preventive medicine, Vol. 12, Issue 1, 16-21.

2. Bakr, W. F. (2010). Assessment of the radiological impact of oil refining industry, Journal of Environmental Radioactivity, Vol. 101, 237-243.

3. Dinh Chau, N. et.al (2011). Natural radioactivity in groundwater-a review. Isotopes in Environmental and Health Studies, Vol. 47, Issue 4, 415-437.

4. Smith, K. P. (2002). An Overwiev of Naturally Occurring Radioactive Materials (NORM) in the Petroleum Industry. ANL/EAIS7 Report, Argonne, Illinois.

5. White, G. J., \& Rood, A. S. (2001). Radon emanation from NORM-contaminated pipe scale and soil at petroleum industry sites. Journal of Environmental Radioactivity, Vol. 54, 401-413.

6. Godoy, J. M., \& Cruz, R. P. (2003). ${ }^{226} \mathrm{Ra}$ and ${ }^{228} \mathrm{Ra}$ in scale and sludge samples and their correlation with the chemical composition. Journal of Environmental Radioactivity, Vol. 70, 199-206.

7. Hamlat, M. S., Djeffal, S., \& Kadi, H. (2001). Assessment of radiation exposures from naturally occurring radioactive materials in the oil and gas industry. Applied Radiation and Isotopes, Vol. 55, 141-146.

8. Ceccarello, S., Black, S., Read, D., \& Hodson, M. E. (2004). Industrial radioactive barite scale: suppression of radium uptake by introduction of competing ions. Minerals Engineering, Vol. 17, 323-330.

9. Rich, A. L., \& Crosby, E. C. (2013). Analysis of Reserve Pit Sludge from Unconventional Natural Gas Hydraulic Fracturing and Drilling Operations for the Presence of Technologically Enhanced Naturally Occurring Radioactive Material (TENORM). New Solutions, Vol. 23, Issue 1, 117-135.

10. Brown, V. J. (2014). Radionuclides in Fracking Wastewater: Managing a Toxic Blend. Environmental Health Perspectives, Vol. 122, Issue 2, A51-A55.

11. Nelson, A. W., Johns, A. W., et al. (2016). Partitioning of Naturally-Occurring radionuclides (NORM) in Marcellus Shale produced fluids influenced by chemical matrix. Environmental Science: Processes \& Impacts, Vol. 18, 456.

12. Washington, D. C. (2006). Radioactive Waste from Oil and Gas Drilling, EPA 402-F-06-038. Retrieved from http://www.epa.gov/radtown/docs/drilling-waste.pdf.

13. Birchall, A., Puncher, M., et al. (2003). IMBA expert(r): Internal dosimetry made simple. Radiation Protection Dosimetry, Vol. 105, 421-425.

14. Maxwell, S. L., III; Culligan, B. K., Warren, R. A., \& McAlister, D. R. (2016). Rapid method for the determination of ${ }^{226}$ Ra in hydraulic fracturing wastewater samples. Journal of Radioanalytical and Nuclear Chemistry, Vol. 309, 1333-1340.

15. Birchall, A., Puncher, M., et al. (2006). IMBA Professional Plus: a flexible approach to internal dosimetry. Radiation Protection Dosimetry, Vol. 125, 194-197.

16. Eitrheim, E. S., May, D., Forbes, T. Z., \& Nelson, A. W. (2016). Disequilibrium of Naturally Occurring Radioactive Materials (NORM) in Drill Cuttings from a Horizontal Drilling Operation. Environmental Science \& Technology Letters, Vol. 3, 425-429. 